\title{
Kardiologiczne konsultacje w ortopedii u chorych przyjmujących leki przeciwzakrzepowe
}

\section{Cardiovascular assessment and management in orthopaedic patients using antithrombotic therapy}

\author{
Radosław Bartkowiak ${ }^{1}$, Beata Wożakowska-Kapłon ${ }^{1,2}$ \\ ${ }^{1}$ I Klinika Kardiologii i Elektroterapii Świętokrzyskiego Centrum Kardiologii w Kielcach \\ ${ }^{2}$ Wydział Nauk o Zdrowiu Uniwersytetu Jana Kochanowskiego w Kielcach
}

\section{Streszczenie}

Istotna część chorych wymagających operacyjnego leczenia ortopedycznego przewlekle przyjmuje leki przeciwzakrzepowe ze wskazań kardiologicznych. Do leków przeciwzakrzepowych należą antagoniści witaminy K (warfaryna i acenokumarol), bezpośredni inhibitor trombiny (dabigatran) oraz bezpośrednie inhibitory czynnika Xa (riwaroksaban i apiksaban). W pracy przedstawiono niezbędne informacje dotyczące stosowania tych leków w okresie okołooperacyjnym oparte na obowiązujących wytycznych i stanowiskach Europejskiego Towarzystwa Kardiologicznego.

Słowa kluczowe: operacja niekardiochirurgiczna, leczenie przeciwzakrzepowe, doustne leki przeciwzakrzepowe, terapia pomostowa

(Folia Cardiologica 2015; 10, 6: 423-427)

\section{Wstęp}

Zabiegi operacyjne w ortopedii często dotyczą chorych w podeszłym wieku dodatkowo obciążonych wieloma współistniejącymi schorzeniami. U pacjentów poddawanych zabiegom ortopedycznym choroby serca mogą być przyczyną powikłań w trakcie operacji lub w okresie pooperacyjnym. Ryzyko wystąpienia sercowo-naczyniowych powikłań okołooperacyjnych zależy od obecności schorzeń układu krążenia, rodzaju operacji oraz okoliczności jej wykonywania (planowa lub nagła) [1]. Każda operacja wywołuje reakcję stresową, która jest inicjowana przez uszkodzenie tkanek, a następnie przekazywana przez czynniki neuroendokrynne. Zabieg chirurgiczny wpływa również na zmianę równowagi w układzie hemostazy, czego efektem jest nadmierna krzepliwość (wzrost stężenia fibrynogenu i innych czynników krzepnięcia, zwiększenie liczby płytek krwi oraz ich aktywacja, zahamowanie procesów fibrynolizy). Zakres powyższych zmian jest proporcjonalny do rozległości zabiegu oraz czasu jego trwania. Najważniejsze w ocenie kardiologicznej przed zabiegiem ortopedycznym są czynniki specyficzne dla danego pacjenta, ale podczas kompleksowej oceny chorego nie można także pominąć rodzaju operacji [1].

Ze względu na niebezpieczeństwo wystąpienia powikłań kardiologicznych można wyróżnić zabiegi chirurgiczne niskiego, umiarkowanego i wysokiego ryzyka wystąpienia incydentu sercowego (zgon z przyczyn sercowo-naczyniowych lub zawał serca) w ciągu 30 dni od operacji [2]. Małe zabiegi ortopedyczne (do takich eksperci zaliczają operacje kolana) są związane z niską częstością występowania (< 1\%) incydentów sercowych. Duże zabiegi ortopedyczne (w obrębie biodra i bliższego odcinka kości udowej) oraz neurochirurgiczno-ortopedyczne (w obrębie kręgosłupa) wiążą

Adres do korespondencji: dr n. med. Radosław Bartkowiak, I Klinika Kardiologii i Elektroterapii, Świętokrzyskie Centrum Kardiologii,

ul. Grunwaldzka 45, 25-736 Kielce, e-mail: radekb@mp.pl 
się z umiarkowanym ryzykiem (1-5\%) wystąpienia incydentów sercowych. Dlatego tak ważne jest właściwe przygotowanie przedoperacyjne, często obejmujące konsultację kardiologiczną u chorego obciążonego zwiększonym ryzykiem powikłań sercowo-naczyniowych [2]. Chorzy obciążeni kardiologicznie często przyjmują leki istotnie wpływające na funkcję układu krzepnięcia (leki przeciwpłytkowe w terapii choroby wieńcowej i ostrych zespołów wieńcowych, leki przeciwzakrzepowe stosowane w migotaniu przedsionków lub po implantacji sztucznych zastawek serca). Optymalne przygotowanie chorego przyjmującego przewlekle leki przeciwzakrzepowe, poprzez modyfikację farmakoterapii - tak aby można było skutecznie i bezpiecznie przeprowadzić zabieg operacyjny, jest bardzo ważne i wymaga ścisłej współpracy oraz porozumienia ortopedy i kardiologa. Stosowanie terapii przeciwzakrzepowej jest związane ze wzmożonym krwawieniem podczas zabiegów chirurgicznych. U pacjentów obciążonych wysokim ryzykiem powikłań zatorowo-zakrzepowych korzyści płynące z leczenia przeciwzakrzepowego przewyższają ryzyko powikłań krwotocznych i terapia ta powinna być kontynuowana lub zmodyfikowana z zachowaniem minimalnego okresu bez leczenia. U pacjentów cechujących się niskim ryzykiem zakrzepicy terapia przeciwkrzepliwa powinna być przejściowo wstrzymana w celu ograniczenia powikłań związanych z krwawieniem w okresie okołooperacyjnym.

\section{Antagoniści witaminy $\mathrm{K}$}

W niektórych grupach pacjentów ryzyko powikłań zatorowo-zakrzepowych jest na tyle wysokie, że muszą oni przyjmować przewlekle leki przeciwzakrzepowe. W bardzo licznej populacji chorych z niezastawkowym migotaniem przedsionków o konieczności terapii przeciwzakrzepowej decyduje ocena ryzyka zakrzepicy przy użyciu skali $\mathrm{CHA}_{2} \mathrm{DS}_{2}$-VASc (Congestive heart failure/LV dysfunction, Hypertension, Age, Diabetes mellitus, Stroke, Vascular Disease, Age, Sex category). Chorzy, którzy uzyskali co najmniej 1 punkt w skali $\mathrm{CHA}_{2} \mathrm{DS}_{2}$-VASc, mają wskazania do przewlekłej antykoagulacji [3]. Pacjentów przyjmujących leki z grupy doustnych antagonistów witaminy $K$ (VKA, vitamin K antagonists) cechuje podwyższone ryzyko krwawienia w trakcie zabiegu operacyjnego i w okresie pooperacyjnym. Przewlekłe leczenie przeciwzakrzepowe za pomocą VKA (warfaryna i acenokumarol) monitoruje się, oceniając wartości międzynarodowego współczynnika znormalizowanego (INR, international normalized ratio) czasu protrombinowego. Zakres terapeutyczny wartości INR u większości chorych leczonych VKA wynosi 2,0-3,0 (2,5-3,5 w niektórych przypadkach po implantacji sztucznej zastawki serca). Gdy po zmniejszeniu dawki VKA lub odstawieniu leku przed operacją INR wynosi mniej niż 1,5, to ryzyko wystąpienia powikłań krwotocznych zmniejsza się znamiennie, a zabieg operacyjny można bezpiecznie wykonać. W przypadku przerwania terapii przeciwzakrzepowej na krótki czas (do 7 dni) w grupie chorych z niezastawkowym migotaniem przedsionków oraz wynikiem 1-3 punktów w skali $\mathrm{CHA}_{2} \mathrm{DS}_{2}$-VASc nie ma potrzeby wdrażania terapii pomostowej [2]. Podstawą takiego schematu leczenia jest zaobserwowana wyraźna zależność między wystąpieniem powikłań krwotocznych w okresie okołooperacyjnym a stosowaniem w terapii pomostowej heparyną drobnocząsteczkową (LMWH, low-molecular-weight heparin). Jednocześnie nie wykazano korzystnego wpływu LMWH na obniżenie częstości powikłań zatorowo-zakrzepowych w okresie okołooperacyjnym w tej grupie chorych. W przypadku niektórych niewielkich zabiegów chirurgicznych związanych z niskim ryzykiem krwawienia (np. drobne zabiegi w obrębie skóry) można kontynuować leczenie przeciwzakrzepowe VKA i utrzymywać INR w zakresie terapeutycznym. Jednak u chorych obciążonych wysokim ryzykiem zakrzepowo-zatorowym nawet krótkotrwałe przerwanie terapii przeciwzakrzepowej może być niebezpieczne i niezbędna jest terapia pomostowa [4, 5]. Zgodnie z wytycznymi do grupy wysokiego ryzyka zakrzepowo-zatorowego zalicza się: chorych z niezastawkowym migotaniem przedsionków i co najmniej 4 punktami w skali $\mathrm{CHA}_{2} \mathrm{DS}_{2}$-VASc, chorych z mechanicznymi protezami zastawek serca, chorych po implantacji biologicznej zastawki serca lub po plastyce zastawki mitralnej w ostatnich 3 miesiącach, chorych po przebytym w ostatnich 3 miesiącach epizodzie żylnej choroby zakrzepowo-zatorowej (VTE, venous thromboembolism) oraz pacjentów z trombofilią. W terapii pomostowej można stosować heparynę niefrakcjonowaną (UFH, unfractionated heparin), ale obecnie zdecydowanie częściej wykorzystuje się LMWH podawaną podskórnie (s.c., subcutaneous) w dawce terapeutycznej. W badaniach klinicznych uzyskano dowody na lepszą skuteczność i większe bezpieczeństwo zastosowania LMWH niż UFH w terapii pomostowej w grupie chorych obciążonych wysokim ryzykiem zakrzepicy $[4,5]$. W populacji chorych z grupy wysokiego ryzyka powikłań zatorowo-zakrzepowych leki z grupy VKA (Warfin ${ }^{\circledR}$, Acenocumarol WZF $^{\circledR}$, Syncumar ${ }^{\circledR}$, Sintrom ${ }^{\circledR}$ ) odstawia się 5 dni przed zabiegiem operacyjnym (czyli nie podaje się 5 ostatnich zaplanowanych dawek VKA przed dniem operacji). Pierwszą dawkę UFH lub LMWH chory przyjmuje dzień po odstawieniu acenokumarolu lub 2 dni po odstawieniu warfaryny. W terapii pomostowej u chorych z grupy wysokiego ryzyka zakrzepowo-zatorowego trzeba stosować dawki terapeutyczne (np. $1 \mathrm{mg} / \mathrm{kg}$ mc. $2 \times /$ d. s.c. lub $1,5 \mathrm{mg} / \mathrm{kg} \mathrm{mc.} \mathrm{raz/d}$. s.c. enoksaparyny). Ostatnia dawka LMWH powinna być podana co najmniej 12 godzin przed zabiegiem operacyjnym (tab. 1). U chorych przewlekle leczonych VKA w dniu zabiegu operacyjnego należy wykonać kontrolę wartości INR. W przypadku INR przekraczającego 1,5 należy rozważyć odroczenie zabiegu. Zastosowanie procedury opartej na codziennej kontroli INR można także rozważyć w szcze- 
Tabela 1. Postępowanie w okresie okołooperacyjnym u chorych przyjmujących przewlekle antagonistów witaminy K (VKA, vitamin K antagonists) zależnie od ryzyka zakrzepicy (źródło [2, 4])

\begin{tabular}{ll}
\hline Niskie ryzyko zakrzepicy & Wysokie ryzyko zakrzepicy \\
\hline $\mathrm{AF}+1-3$ pkt. w skali $\mathrm{CHA}_{2} \mathrm{DS}_{2}$-VASc & $\mathrm{AF}+\geq 4$ pkt. w skali $\mathrm{CHA}_{2} \mathrm{DS}_{2}$-VASc \\
& Mechaniczna proteza zastawkowa \\
& Biologiczna zastawka $<3$ miesiące \\
& Naprawa zastawki mitralnej $<3$ miesiące \\
& VTE $<3$ miesiące \\
& Trombofilia \\
& Postępowanie \\
\hline Odstawić/zmniejszyć dawkę VKA & Terapia pomostowa (UFH lub LMWH) w dawce terapeutycznej: \\
Bez terapii pomostowej & - LMWH preferowana względem UFH \\
Operacja, jeśli INR $<1,5$ & $-1,5 \mathrm{mg} / \mathrm{kg}$ mc. raz/d. s.c. \\
& $-1 \mathrm{mg} / \mathrm{kg}$ mc. $2 \times /$ d. s.c. \\
& - ostatnia dawka $>12 \mathrm{~h}$ przed zabiegiem
\end{tabular}

AF (atrial fibrillation) - migotanie przedsionków; $\mathrm{CHA}_{2} \mathrm{DS} \mathrm{S}_{2}$-VASc (Congestive heart failure/LV dysfunction, Hypertension, Age, Diabetes mellitus, Stroke, Vascular Disease, Age, Sex category) - punktowa skala ryzyka powikłań zatorowo-zakrzepowych u chorych z niezastawkowym AF; VTE (venous thromboembolism) - żylna choroba zakrzepowo-zatorowa; UFH (unfractionated heparyn) - heparyna niefrakcjonowana; LMWH (low-molecular-weight heparin) - heparyna drobnocząsteczkowa; s.c. (subcutaneous) - podskórnie

Tabela 2. Postępowanie w okresie okołooperacyjnym u chorych przyjmujących przewlekle warfarynę lub acenokumarol (innego antagonistę witaminy $\mathrm{K}$ [VKA, vitamin $\mathrm{K}$ antagonist]) - prezentacja osi czasu (na podstawie [2, 4])

\begin{tabular}{|c|c|c|c|c|c|c|c|}
\hline$-4 d n i$ & $-3 d n i$ & $-2 d n i$ & -1 dzień & Operacja & +1 dzień & $+2 \mathrm{dni}$ & $+3 \mathrm{dni}$ \\
\hline \multirow[t]{2}{*}{$\begin{array}{l}\text { Odstaw } \\
\text { warfarynę }\end{array}$} & & $\begin{array}{l}\text { Zastosuj } \\
\text { LMWH }\end{array}$ & LMWH rano & Bez leków & $\begin{array}{c}\text { Ocena } \\
\text { hemostazy }\end{array}$ & $\begin{array}{c}\text { Podaj } \\
\text { LMWH + VKA }\end{array}$ & $\begin{array}{c}\text { Obserwuj i podaj } \\
\text { LMWH + VKA }\end{array}$ \\
\hline & $\begin{array}{l}\text { Odstaw } \\
\text { inny VKA }\end{array}$ & $\begin{array}{c}\text { Zastosuj } \\
\text { LMWH }\end{array}$ & LMWH rano & Bez leków & $\begin{array}{c}\text { Ocena } \\
\text { hemostazy }\end{array}$ & $\begin{array}{c}\text { Podaj } \\
\text { LMWH + VKA }\end{array}$ & $\begin{array}{c}\text { Obserwuj i podaj } \\
\text { LMWH + VKA }\end{array}$ \\
\hline
\end{tabular}

LMWH (low-molecular-weight heparin) - heparyna drobnocząsteczkowa

gólności u chorych hospitalizowanych. W tym przypadku podawanie LMWH należy rozpoczynać dzień po przerwaniu terapii za pomocą VKA lub później, jeśli INR wynosi mniej niż 2,0 [2]. Z kolei w podgrupie chorych po wszczepieniu sztucznej zastawki serca uzyskano dowody przemawiające za dożylnym podawaniem UFH zamiast dożyInych iniekcji LMWH [4]. Dożylny wlew heparyny pod kontrolą czasu częściowej tromboplastyny do aktywacji (APTT, activated partial thromboplastin time) przerywa się 4 godziny przed zabiegiem operacyjnym. Ponowne zastosowanie leczenia przeciwzakrzepowego po operacji zależy od uzyskania prawidłowej kontroli hemostazy. Decyzję powinien podjać operator wykonujący zabieg. Zazwyczaj chory otrzymuje leki przeciwzakrzepowe ponownie w pierwszym lub drugim dniu po operacji, jednak nie wcześniej niż po 12 godzinach. Ponowna inicjacja terapii przeciwzakrzepowej po operacji polega na jednoczasowym stosowaniu VKA oraz LMWH lub UFH. Leczenie za pomocą VKA należy rozpoczynać od dawki przedoperacyjnej zwiększanej o 50\% przez 2 pierwsze dni. Heparyna niefrakcjonowana dożylnie lub LMWH s.c. powinny być stosowane do czasu, gdy wartość INR będzie przekraczała 2,0 przez 2 kolejne dni [2] (tab. 2). Warto za- uważyć, że wystąpienie istotnego powikłania krwotocznego w okresie pooperacyjnym w związku ze zbyt pospiesznym zastosowaniem leków przeciwkrzepliwych u chorego bez pełnej kontroli hemostazy skutkuje dalszym wstrzymaniem leczenia przeciwzakrzepowego, a co za tym idzie - zwiększa również ryzyko powikłań zakrzepowo-zatorowych.

$\mathrm{U}$ chorych przyjmujących przewlekle VKA, którzy wymagają pilnego zabiegu ortopedycznego, można odwrócić efekt przeciwzakrzepowy, podając witaminę $\mathrm{K}$ dożyInie lub doustnie $w$ małej dawce $(2,5-5 \mathrm{mg})$. W tym przypadku wpływ podania preparatu witaminy $\mathrm{K}$ na obniżenie wartości INR ujawni się po 12-24 godzinach. W celu bardzo szybkiego odwrócenia efektu przeciwzakrzepowego zaleca się podanie świeżo mrożonego osocza lub koncentratu czynników kompleksu protrombiny łącznie z małą dawką witaminy $\mathrm{K}$. W grupie chorych otrzymujących UFH we wlewie dożylnym i wymagających pilnej operacji należy przerwać podawanie leku i odroczyć zabieg o 4 godziny, ponieważ po tym czasie krzepnięcie jest już zazwyczaj prawidłowe. W celu natychmiastowego odwrócenia działania przeciwkrzepliwego UFH jako swoiste antidotum stosuje się siarczan protaminy w odpowiednio wyliczonej dawce. U chorych otrzymujących 
Tabela 3. Postępowanie w okresie okołooperacyjnym u chorych przyjmujących dabigatran zależnie od rodzaju operacji i oceny czynności nerek (źródło [7])

$\begin{array}{lcc}\text { Klirens kreatyniny }(\mathrm{CrCl})[\mathrm{ml} / \mathrm{min}] & \text { Niskie ryzyko operacji }[\mathrm{h}] & \text { Wysokie ryzyko (biodro/udo })[\mathrm{h}] \\ >80 & >24(1 \mathrm{dzień}) & >48(2 \mathrm{dni}) \\ 50-79 & >36(1,5 \mathrm{dnia}) & >72(3 \mathrm{dni}) \\ 30-49 & >48(2 \mathrm{dni}) & >96(4 \mathrm{dni})\end{array}$

$\mathrm{CrCl}$-creatinine clearance

LMWH s.c. działanie przeciwkrzepliwe leku znamiennie zmniejsza się po około 8 godzinach od przyjęcia ostatniej dawki. Jeśli wymagane jest natychmiastowe odwrócenie działania LMWH, to można podać dożylnie siarczan protaminy, ale aktywność anty-Xa nie zostaje w tym przypadku całkowicie zneutralizowana.

\section{Doustne leki przeciwzakrzepowe niebędące antagonistami witaminy $\mathrm{K}$}

Nowe doustne leki przeciwkrzepliwe o bezpośrednim działaniu niebędące antagonistami witaminy K (NOAC, non-vitamin $K$ oral anticoagulants) stanowią przełom w terapii. Mimo wysokich kosztów przewlekłego leczenia (brak refundacji narodowego płatnika we wskazaniu „niezastawkowe migotanie przedsionków") zdobywają coraz większe zaufanie pacjentów i lekarzy. Obecnie w Polsce są zarejestrowane trzy leki z grupy NOAC - dabigatran (bezpośredni inhibitor trombiny), riwaroksaban i apiksaban (bezpośrednie inhibitory czynnika Xa). Ortopedyczny zabieg operacyjny jest jedną z sytuacji klinicznych, w których należy czasowo wstrzymać przyjmowanie NOAC. Nie ma wątpliwości, że profil farmakokinetyczny NOAC jest zupełnie odmienny od profilu farmakokinetycznego VKA. W odróżnieniu od VKA nowe leki przeciwzakrzepowe cechują się bardzo szybkim początkiem działania (1-3 h) oraz krótszym i przewidywalnym w przypadku danego leku czasem działania. Dlatego NOAC mogą być odstawiane na istotnie krótszy okres niż VKA [6]. Jest to korzystne dla chorych, ponieważ przez krótszy czas pozostają bez ochrony przeciwzakrzepowej, a to z kolei prowadzi do obniżenia ryzyka powikłań zakrzepowo-zatorowych. Przejściowe przerwanie terapii za pomocą NOAC prowadzi oczywiście do zminimalizowania ryzyka powikłań krwotocznych w trakcie operacji oraz w okresie pooperacyjnym, co ma szczególne znaczenie w związku z brakiem powszechnie dostępnych środków umożliwiających szybkie odwrócenie działania przeciwkrzepliwego. Problemem pozostaje jedynie określenie optymalnego czasu przerwania terapii z użyciem NOAC przed zabiegiem operacyjnym. Najbardziej szczegółowej i aktualnej informacji w tym zakresie dostarcza dokument European Heart Rhythm Association (EHRA) opublikowany w 2013 roku [7]. Przed podjęciem decyzji o przerwaniu doustnej antykoagulacji z użyciem NOAC należy ocenić ryzyko krwawienia związane z planowanym zabiegiem operacyjnym, które może być małe (małe zabiegi ortopedyczne, endoprotezoplastyka stawu kolanowego) lub duże (zabiegi ortopedyczne dotyczące bliższego odcinka kości udowej lub stawu biodrowego). W przypadku stosowania dabigatranu (w $80 \%$ eliminowanego drogą nerkową) należy również uwzględnić stopień zaburzenia czynności nerek [8]. U pacjentów poddawanych zabiegom operacyjnym związanym z małym ryzykiem powikłań krwotocznych riwaroksaban i apiksaban należy odstawić 24 godziny wcześniej, niezależnie od klirensu kreatyniny. Natomiast przed zabiegami operacyjnymi obarczonymi dużym ryzykiem krwawienia riwaroksaban i apiksaban należy odstawić co najmniej 48 godzin (2 doby) wcześniej. Czas przerwania terapii dabigatranem zależy od stopnia dysfunkcji nerek i w przypadku zabiegów operacyjnych o małym ryzyku powikłań krwotocznych wynosi od 24 godzin przy klirensie kreatyniny większym lub równym $80 \mathrm{ml} / \mathrm{min}$ do 48 godzin przy klirensie kreatyniny poniżej $50 \mathrm{ml} / \mathrm{min}$. W przypadku zabiegów związanych z dużym ryzykiem powikłań krwotocznych wynosi od 48 godzin przy klirensie kreatyniny większym lub równym $80 \mathrm{ml} / \mathrm{min}$ do nawet 96 godzin (czyli 4 dni) przy klirensie kreatyniny mniejszym niż $50 \mathrm{ml} / \mathrm{min}$. Szczegółowe dane przedstawiono w tabeli 3 . U chorych przyjmujących dabigatran poddawanych operacjom obciążonym dużym ryzykiem zagrażających życiu powikłań krwotocznych (w ortopedii np. znieczulenie rdzeniowe do zabiegu) wskazane jest oznaczenie APTT przed operacją [9]. Prawidłowy wynik badania wskazuje bowiem na nieistotne stężenie dabigatranu. Obecnie nie ma takiego prostego testu do orientacyjnej oceny odwrócenia działania przeciwkrzepliwego riwaroksabanu i apiksabanu. W przypadku stosowania NOAC zwykle nie jest konieczna terapia pomostowa, gdyż - w przeciwieństwie do VKA - krótki okres półtrwania leków z tej grupy umożliwia zaprzestanie ich stosowania istotnie bliżej terminu operacji. $\mathrm{U}$ chorych przyjmujących NOAC istotne ryzyko krwawienia występuje także po zabiegu operacyjnym, ponieważ pełny efekt przeciwkrzepliwy występuje bardzo szybko (1-3 h) po doustnym podaniu leku. Odróżnia to istotnie NOAC od warfaryny i acenokumarolu, których działanie przeciwkrzepliwe rozwija się w ciągu kilku dni od rozpoczęcia podawania. Rozsądnym rozwiązaniem może być zastosowanie profilaktycznych dawek LMWH z przywróceniem stosowania NOAC w 3. lub 4. dobie po operacji, po 24 godzinach od podania 
ostatniej dawki LMWH [2]. W przypadku pilnej interwencji chirurgicznej u chorych przyjmujących przewlekle NOAC nie zaleca się rutynowego, profilaktycznego podawania świeżo mrożonego osocza, koncentratu czynników zespołu protrombiny ani rekombinowanego czynnika VIla. Jeśli to możliwe, zabieg operacyjny należy odroczyć o co najmniej
12 godzin od przyjęcia przez pacjenta ostatniej dawki leku [10].

\section{Konflikt interesów}

Autorzy nie zgłaszają konfliktu interesów.

\section{Abstract}

Significant part of patients who require orthopaedic surgery receives long-term antithrombotic therapy due to cardiological reasons. Among oral anticoagulants we have vitamin $\mathrm{K}$ antagonists (warfarin and acenocoumarol), a direct thrombin inhibitor (dabigatran) and direct factor Xa inhibitors (rivaroxaban, apixaban). In the article we present necessary information about proper antithrombotic treatment during the perioperative period based on European Cardiac Society guidelines and position statements.

Key words: non-cardiac surgery, antithrombotic therapy, oral anticoagulants, bridging therapy

(Folia Cardiologica 2015; 10, 6: 423-427)

\section{Piśmiennictwo}

1. Wirthlin D.J., Cambria R.P. Surgery-specific considerations in the cardiac patients undergoing noncardiac surgery. Prog. Cardiovasc. Dis. 1998; 40: 453-468.

2. Kristensen S.D., Knuuti J., Saraste A. i wsp. Wytyczne ESC/ESA dotyczące operacji niekardiochirurgicznych - ocena ryzyka sercowo-naczyniowego i postępowanie w 2014 roku. Kardiol. Pol. 2014; 72: 857-918.

3. European Heart Rhythm Association; European Association for Cardio-Thoracic Surgery, Camm A.J., Kirchhof P., Lip GY i wsp. Guidelines for the management of atrial fibrillation: the Task Force for the Management of Atrial Fibrillation of the European Society of Cardiology (ESC). Eur. Heart J. 2010; 31: 2369-2429.

4. Joint Task Force on the Management of Valvular Heart Disease of the European Society of Cardiology (ESC); European Association for Cardio-Thoracic Surgery (EACTS), Vahanian A., Alfieri O., Andreotti F i wsp. Guidelines on the management of valvular heart disease (version 2012). Eur. Heart J. 2012; 33: 2451-2496.

5. Pengo V., Cucchini U., Denas G. i wsp. standarized low-molecular-weight heparin bridging regimen in outpatients on oral anticoagulants undergoing invasive procedure or surgery an inception cohort management study. Circulation 2009; 119: 2920-2927.

6. Huber K., Connolly S.J., Kher A. i wsp. Practical use of dabigatran etexilate for stroke prevention in atrial fibrillation. Int. J. Clin. Pract. 2013; 67: 516-526.

7. Heidbuchel H., Verhamme P., Aligns M. i wsp. European Heart Rhythm Association Practical Guide on the use of new oral anticoagulants in patients with non-valvular atrial fibrillation. Europace 2013; 15: 625-651.

8. Periprocedural management and approach to bleeding in patients taking dabigatran. Circulation 2012; 126: 2428-2432.

9. Camm A.J., Lip G.Y., De Caterina R. i wsp. 2012 focused update of the ESC Guidelines for the management of atrial fibrillation: an update of the 2010 ESC Guidelines for the management of atrial fibrillation. Developed with the special contribution of the European Heart Rhythm Association. Eur. Heart J. 2012; 33: 2719-2747.

10. De Caterina R., Husted S., Wallentin L. i wsp. New oral anticoagulants in atrial fibrillation and acute coronary syndromes: ESC Working Group on Thrombosis-Task Force on Anticoagulants in Heart Disease position paper. J. Am. Coll. Cardiol. 2012; 59: 1413-1425. 